\title{
Lateral
}

Journal of the Cultural Studies Association

\section{Review of Palestinian Theatre in the West Bank: Our Human Faces by Gabriel Varghese (Palgrave MacMillan)}

\begin{abstract}
by Joshua Hamzehee | Book Reviews, Issue 9.2 (Fall 2020)
ABSTRACT In Palestinian Theatre in the West Bank: Our Human Faces, Varghese traces five Palestinian theatre companies-Al-Kasaba Theatre, Ashtar for Theatre Productions and Training, Al-Harah Theatre, The Freedom Theatre, and Al-Rowwad Cultural and Theatre Training Society-from the first intifada (1987-93), or uprising, to today, to show how abject counterpublics in the West Bank resist Zionist erasure narratives. In the book, Varghese weaves thick description of examples and performances with historical contextualization to draw readers into what motivates Palestinian theatre-makers. Varghese shows there is potential for resistance through the border anxiety developed in sites of colonial abjection. Ultimately, this text argues Palestinian theatres in the West Bank do more than just perform plays-they provide needed space where issues are exposed, communities gather, and marginalization is responded to with beautiful resistance.
\end{abstract}

KEYWORDS counterpublics, decolonial, $\underline{\text { Palestine, }}$ theatre, West Bank

Palestinian Theatre in the West Bank: Our Human Faces. By Gabriel Varghese. Cham, Switzerland: Palgrave MacMillan, 2020, 166 pp. (eBook) ISBN 978-3-030-30246-7. US List: $\$ 64.99$.

Theatre reflects the plights of its creators and the contexts of its creation. It is therefore no wonder that Gabriel Varghese's new book argues that theatre plays a vital role in "Palestinian national liberation by contesting Zionist discourse, spotlighting Israeli state practices and reclaiming the very narrative on Palestine itself" (2). Palestinian Theatre in the West Bank: Our Human Faces traces five Palestinian theatre companies-Al-Kasaba Theatre, Ashtar for Theatre Productions and Training, Al-Harah Theatre, The Freedom Theatre, and Al-Rowwad Cultural and Theatre Training Society-from the first intifada (1987-93), or uprising, to today. Varghese argues that these theatre companies act as counterpublics resisting and responding to colonial abjection. Palestinian Theatre in the West Bank shows that Palestinians sharing stories through theatre is activism because it proclaims, in the face of Zionist erasure: "I am human."

Varghese gathered data from fieldwork and site visits, interviewing key theatre-makers, and participating in productions. I appreciate how Varghese weaves thick description of examples and performances with historical contextualization to draw readers into what motivates Palestinian theatre-makers. While the text is not bogged down with methodology, additional details about the author's research practices would have been helpful. 
Chapter 1 provides historical and theoretical overviews of abjection, counterpublics, and border thinking, setting the stage for the following chapters. Varghese unpacks abjection -or, oppressed subjects being cast as less than human by oppressive groups-and introduces the concept of abject counterpublics. Varghese notes the potential for resistance through border anxiety developed in sites of colonial abjection. Palestinian theatre-makers create atop the residual phenomena of the past, therefore articulation of Palestinian culture is counter-hegemonic "because it attempts to unravel Israel's foundational myth that Palestinians simply do not exist" (10).

Chapter 2, "Cultural Intifada, Beautiful Resistance," covers the past forty years of five theatre companies that continue to perform today. Traveling through the War of 1967, the first intifada, and the 1993 Oslo Accords, Varghese's accounts of the companies read like succinct Wikipedia entries in the best way possible, providing context and description without being overwhelming. While each company uses diverse theatrical techniques to critique their situations, Palestinian theatrical resistance to Israeli dominance is not without struggle: performing in refugee camps and for children, the ethics of performing lived experiences, and Israeli targeting of Palestinian cultural institutions with censorship and violence, all constitute sites of challenge. Varghese argues these theatres do more than just perform plays-they provide needed space where issues are exposed, communities gather, and marginalization is responded to with beauty and craft.

Chapters 3, 4, and 5 are case studies of abject counterpublics, created by the clash of Palestinian theatre with the Zionist public sphere. In Chapter 3, "Aren't We Human?," Varghese expands on projects from Al-Kasaba Theatre, Al-Rowwad, Ashtar, and The Freedom Theatre. Their subject matters draw on occupation, murder, aerial bombardment, ground invasion, and even Palestinian leadership. Varghese writes about one monologue, specifically, from Al-Kasaba Theatre's Alive from Palestine: Stories Under Occupation:

A father is going through his son's school bag. In it, he finds an apple, a sandwich, a pencil, and a sketchbook. He speaks to his son as though he were sitting in front of him, gently scolding him for wanting things the father cannot provide because the roadblocks prevent him from travelling to the shops (59).

One paragraph later:

The audience realizes his son is dead. We are not told how he died but, from the broader context of the scene, we might assume that he was killed by one of the soldiers at his school. The apple and half-eaten sandwich were his lunch.

Varghese suggests that by "articulating the personal, Palestinians call attention to their abjection and, at the same time, disidentify with the very processes by which they are rendered abject" (85). This chapter also focuses on Al-Rowwad's We are the Children of the Camp, Ashtar's The Gaza Monologues, and The Freedom Theatre's US civil rightsinspired Freedom Ride.

In Chapter 4, "A Stage of One's Own," Varghese hones in on Al-Harah Theatre's Shakespeare's Sisters, stating it is "an attempt by women theatre-makers to question the high value Palestinian society places on the patriarchal roles of wife and mother" (91). This chapter provides a look into the show's impetus and development, and how intersections of age, gender, and familial pressures affect Palestinian women through patriarchal bargaining. 
Chapter 5, "Acting on the Pain of Others," is more praxis-based. Varghese explores theatrical collaboration through The Freedom Theatre's Our Sign is the Stone and Ashtar's This Flesh is Mine. He unpacks the power dynamics inherent in Palestinian theatres' consistent need for Western funding, as "imbalance always precedes collaborations" like these (120). Drawing on his firsthand experience, Varghese notes the importance of community ownership and shared political languages for practitioners making Palestinian theatre.

Palestinian Theatre in the West Bank is a concise rundown of the impact settler colonialism has had on Palestinian theatre-makers. Broadly, this book focuses on how decolonial theatre and Palestinian arts movements intersect with race, gender, and class. Some strengths include its vivid descriptions of projects and the wide net cast on lived experiences represented on stage. While one text can only cover so much, I remain curious about how the plays were translated and how methodological choices affected the author's research. While more work can be done to disentangle the nuances behind Zionist self-determination, to tease out the differences between the Black experience and the Palestinian experience and to understand the future implications of activist theatrical movements in the West Bank, this is also work for readers-and not Varghese alone-to take up. Varghese's text is of use to cultural scholars and performance practitioners seeking to understand the West Bank climate through the work of its theatre-makers. As a performance studies educator, I can easily see using portions of this text in my cultural performance courses.

\title{
Author Information
}

\author{
Joshua Hamzehee \\ Josh Hamzehee is the Production Coordinator for University of Northern lowa's \\ Interpreters Theatre. He is a performance scholar<-> practitioner who engages \\ in critical ethnographic methods, spoken-word roots, and remixed performance \\ techniques. Recent projects include Burnt City: A Dystopian Bilingual One- \\ Persian Show, Baton Rouge SLAM!: An Obituary for Summer 2016, and The \\ Deported: A Reality Show!
}

View all of Joshua Hamzehee's articles.

\section{Article details}

Joshua Hamzehee, "Review of 'Palestinian Theatre in the West Bank: Our Human Faces' by Gabriel Varghese (Palgrave MacMillan)," Lateral 9.2 (2020).

https://doi.org/10.25158/L9.2.15

This content is licensed under a Creative Commons Attribution-NonCommercial 4.0 International License. Copyright is retained by authors. 
Lateral is the peer-reviewed, open access journal of the Cultural Studies Association.

ISSN 2469-4053 